\title{
THE INDIVIDUAL, SOCIETY, AND NATURE IN LIMA BARRETO'S THEORY OF LITERATURE
}

\author{
Robert Herron
}

Wilson Martins has said that all literature "is more psychological than sociological in conception and realization, and more sociological than psychological in repercussion and consequences" (1). What he means by this is that the initial impetus and planning of a literary work stems from the individual author and his psychological motivation, and the work itself is a reflection of the writer's psychological makeup and individual beliefs. After the work has been written and published, the reaction of the general public to it constitutes more group than individual behavior. If one considers that the individual writer and his actions are determined by the society and atmosphere in which he lives, however, as Lima Barreto tended to do (though he did not accept this belief entirely), one inevitably concludes the author who writes a book is merely responding to external stimuli, and the ultimate origin of his work is more sociological than psychological. Lima Barreto was strongly influenced by Hippolyte Taine's triad of race, milieu, and moment:

"A arte, por sua natureza mesma, é uma criação humana dependente estreitamente do meio, da raça e do momento - todas essas condições concorrendo concomitantemente" (2)

But, as Wellek and Warren have pointed out, the concept of moment can be easily diluted into the concept of milieu, oven though the former is a time term and the latter is a space term. According to Taine's theory, a work of art is an expression of the environment in which it is written at a given historical moment. Race, so often taken

(1) - Wilson Martins, A Crztica Literária no Brasil (São Paulo, 1952), pp. $73-74$. p. 38 .
(2) - Afonso H. Lima Barreto, Feiras e Mafuás (São Paulo, 1956), 
as hereditary qualities in general, as it is used by Taine is extremely vague, meaning in general a certain "national character" (3).

Although he seemed to emphasize the sociological causes and circumstances accompanying the appearance of a literary work, Lima Barreto did not ignore the individualistic side of its creation. His own experience and observation of life around him was the source of his literature:

"O que escrevo, é o que vejo e sinto diretamente por mim; e os meus humildes escritos não são senão isso e mais as minhas dores e o desabafo de injustiças com que esses souteneurs das letras me têm amar. gurado a existência" (4).

He thought, moreover, that every writer should be individualistic and original and resist the social forces that prevent a person from expressing exactly what he thinks. For that reason he directed a small, obscure, short-lived magazine called Floreal, designed to make available the opportunity of free expression which is not found in the larger and better-known magazines and newspapers:

\footnotetext{
“E' uma revista individualista, em que cada um poderá, pelas suas páginas, com a responsabilidade de sua assinatura, manifestar as suas preferências, comunicar as suas intuições, dizer os seus julgamentos, quaisquer que sejam" (5).
}

He held the opinion that the person who wished to have something published in what he considered the big press must necessarily be already well-known, be a member of one of the powerful and influential classes of society, or at least must yield to their pressures in expressing opinions. There are certain things, then, which a writer must resist in his environment if he is to retain his individuality. In this sense he need not be a slave to Taine's triad, which determines certain elements bound to appear in the work, but does not determine the author's attitude with respect to those elements.

The socio-psychological dualism found in Lima Barreto's ideas about the origin of literature or art is also present in his statements about the principal elements which must be included within a work of fiction. Whereas in discussing the origin of literature Lima Bar-

(3) - René Wellek and Austin Warren, Theory of Literature. (New York, 1962), p. 105. p. 237 .

(4) - Afonso H. Lima Barreto, Impressões de Leitura (São Paulo, 1956),

(5) - Ibid., pp. 181-182. 
reto leaned more heavily on a sociological explanation, in dealing with the work of art itself he gave equal importance to external clements (i. e., social and natural) and individual ones, using the latter as a starting point. To a large extent Lima Barreto's attitude toward the inclusion and balance of environmental factors and individual tendencies is a kind of thesis of the literary tradition (European and Brazilian) which preceded him. He favored a return to the individual Romantic sensitivity, idealism, and to the importance of human values, which had been lost in the schools of Realism and Naturalism, which had attached excessive attention to the outside world and to the consideration of the human being scientifically, as an object, in his most abject state of degradation. Lima Barreto was attracted by naturalism, and even dreamed of writing a naturalistic novel, but his brand of naturalism would have been a more psychological one; that is, one which granted more attention and dignity to the individual:

\footnotetext{
"Pretendo fazer um romance em que se descrevam a vida o o trabalho dos negros numa fazenda. Será uma espécie de Germinal negro, com mais psicologia especial e maior sôpro de epopéia" (6).
}

He also thought that the excesses of fantasy which were observed in Romanticism should be avoided, that the work of art should be plausible, and reflect reality. He believed in a literature of "simpatia humana", which is a reflection in part of Russian writers like Tolstoy and Gorki. These opinions may be deduced in part from an article of his own (7) because of the inspiration it had given him.

If he reacted against the extremes of the Realism and Naturalism which pushed the individual into the background, he also reacted against "psychological" literature which pushed environmental factors almost completely out of the picture in favor of individual characters, a was the case with the novels by Machado de Assís. In his own literary creed Lima Barreto used the individual as a starting point, proclaimed that art was particular (that is, with a preeminence of specific accounts about individual characters), but he felt that an individual character could not be "individualized" without the use of details to explain him, and that those details must involve the character's external appearance and his environment as well as the workings of his mind. In this sense the individual character cannot be separated in the work of art from the meio (both social and physical)

(6) - Afonso H. Lima Barreto, Diário Intimo (São Paulo, 1956), p. 84.

(7) - Lima Barreto, Feiras e Mafuás, pp. 156-163. 
in which he moves. Lima Barreto expressed this view very well in an article he wrote in response to a literary palestra by Pedro Lessa about Machado de Assis. Lessa had seen and praised in Machado de Assis his ability to abstract human emotions, feelings, and reactions. Lima Barreto replied that Machado de Assis had a certain tendency not to explain his characters fully (e. g., he omitted details of physical appearance much of the time and environmental descriptions most of the time) and criticized him for it, but denied that Machado fit into Lessa's category of abstraction:

"O que pensa Vossa Excelência da arte de Machado de Assis e de outros que não conheço, é reduzi-la à análise das almas aos seus sentimentos elementares. Vossa Excelência quer uma espécie de arte-sinaispsíquicos, uma álgebra psicológica, separada de todas as coisas exteriores, desde as montanhas, o mar, até à pigmentação do herói e dos cabelos da heroína. Essa arte algébrica de descrição de sentimentos puros: amor, ciúme, orgulho, vaidade, etc., não conheço, nem mesmo em Machado de Assis. Enfim, eu sou ignorante" (8).

In reality, Machado de Assis was more diametrically opposed to Lima Barreto on this point than the latter wanted to admit at this time. In Dom Casmurro, for example, Machado states that detail in a novel is unnecessary, that the important thing is the essence of the characters and their drama. He implies that the external world is not important and may be left out almost entirely. The reader may supply what is missing by using his imagination:

Nada se emenda bem nos livros confusos, mas tudo se pode meter nos livros omissos. Eu, quando leio algum desta outra casta, não mc aflijo nunca. O que faço, em chegando ao fim, é cerrar os olhos e evocar todas as coisas que não achei nele. Quantas idéias finas me acodem então! Que de reflexões profundas! Os rios, as montanhas, as igrejas que não vi nas folhas lidas, todos me aparecem agora com as suas águas, as suas árvores, os seus altares; e os generais sacam das espada: que tinham, ficado na bainha, e os clarins soltam as notas que dormiam no metal, e tudo marcha com uma alma imprevista.

E' que tudo se acha fora de um livro falho, leitor amigo. Assim preencho as lacunas alheias; assim podes também preencher as minhas (9).

Lima Barreto did not want to leave anything to the reader's imagination, however. He wanted to tell and explain everything:

(8) - Ibid., p. 37.

(9) - Joaquim M. Machado de Assis, Dom Casmurro (São Paulo, 1956), p. 200 . 
A Arte, por ser particular e destinar-se a pintar as ações de fora sobre a alma e vice-versa, não pode desprezar o meio, nás suas mínimas partıcularidades, quando delas precisar.

Tendo que pintar o desgôsto de um leproso, como a sua vida evolui, eu não posso me abater abstratamente ao sentimento 'desgôsto'. E' meu dever primeiramente dizer que ele é leproso, que é rico, que é burro ou inteligente; e, depois, descrever a sua ambiência, tanto de homens, de coisas, mortas e vivas, para narrar, romancear o desgôsto do mesmo leproso. Todos os leprosos, doutor Pedro Lessa, não manifestam a sua dor da mesma maneira; e, para se a compreender artisticamente, são precisos, muitas vezes, detalhes que parecem insignificantes.

Talvez para o psicólogo científico haja, em última análise, só desgôsto; mas, para o artista, esse desgôsto elementar pode ser revestido de muitas formas derivadas (10).

Lima Barreto places great emphasis on the rôle played by a particular atmosphere or setting as well as a particular individual within a work of art. In real life and in literature, the same type of individual in two different settings will act differently:

"Há uma mesma geometria para aqui e para a Lapônia; mas uma Virgília do Rio de Janeiro não pode agir da mesma maneira, levada pelos mesmos motivos sociais, que a Virgília de lá, se as há... De resto os mesmos motivos agindo sobre indivíduos neste meio ou naquele po. dem levá-los a atos diferentes" (11).

What he does not explain sufficiently well is why two different individuals will react differently to the same social and physical setting.

Having seen established Lima Barreto's opinion of the imporlance of the individual character and his surroundings within the work of art, we may now ask how he thought they should be handled and what they should represent artistically $\mathrm{He}$ believed also that individuals and their social and natural setting should be representative of real life. Since he considered the society in which he lived, and all societies, in general, to be corrupt and to the detriment of the individual, he believod that art should have as one function the explanation and condemnation of the existing society-individual relationship.

With reference to ideas, what distinguishes art from pamphleteering is its relative indirectness. Fiction also requires greater indirectness than non-fiction. The main purpose of fiction can never be to indoctrinate or propagandize. It can only suggest, never command. Lima Barreto realized that true art must not be too direct, even though indi-

(10) - Lima Barreto, Feiras e Mafuás, p. 39.

(11) - Ibid., pp. 38-39. 
rectness conflicted somewhat with his desire to win people over to his way of thinking and with his wish to express himself with clarity and simplicity in order to reach the greatest number possible of readers. It can ben deduced from his criticism of a contemporary, Saturnino de Brito, that thought the best ways to artistically, or indirectly, condemn society were satire and irony $\mathrm{He}$ also thought that ideally it was better for the artist to maintain a serene ideological detachment from his work, though his emotional presence within his indirect social condemnation would indicate the very important quality of sincerity:

"O ardor do seu gênio não lhe permite que as suas produções tenham a serenidade de expor fatos, de condená-los artisticamente de modo que digam ao leitor mais do que dizem. O autor se apaixona, declama e abandona-se à eloquiência. Ama a metáfora e a alegoria; e não tem o dom da ironia e da sátira. Tanto nas suas obras de ficção como nas de propaganda, a sua paixão não procura diques; ao contrário, como que se compraz em extravasar por todos os lados. Inunda tudo. Será defeito; mas também é denúncia da sua qualidade superior de escritor: a sua sinceridade" (12).

Though he considered his transmission of ideas about the societyindividual relationship to be the most important thing in literature, $\mathrm{Li}$ ma Barreto thought that artistic means were the only way to make his ideas have any repercussion. To some extent he solved his own dilemma between artistic indirectness and his desire for clarity by sharing his writing time between fiction and non-fiction (short essays, newspaper articles, crônicas). In the latter he expressed his ideas moro clearly and directly; in the former they were more vaguely presented. That he was at least somewhat suocessful in his artistic representation is attested to by Astrojildo Pereira, who tells us that we must read Lima Barreto's short essays to understand the ideology that lurked behind his novels:

"Sem ser um panfletário profissional, imprimia a muitos dos seus artigos a feição de áspera crítica política e social e fazia da sátira de costumes uma arma permanente de combate. São as mesmas características que se encontram na sua obra de ficção e que nos seus artigos aparecem, naturalmente, de modo mais direto e desnudo. E eu acredito quc não se pode aprofundar o conhecimento e a compreensão da sua obra de ficção sem se conhecer e compreender as reflexões e memórias que nos deixou sob a forma de artigos e crônicas de jornal" (13).

(12) - Lima Barreto, Impressões de Leitura, p. 125.

(13) - Astrojildo Pereira, Preface to Bagatelas by Afonso H. Lima Barreto (São Paulo, 1956), pp. 12-13. 
Lima Barreto apparently hoped that his fiction would influence his readers without their consciousness of being affected by his ideas. $\mathrm{He}$ also considered art the only way to reach and stir the averago Brazilian reader, who in his opinion was most probably intelecctually lazy. For that reason he advised even writers of essays, who have a greater liberty in expressing their ideas directly, to adorn their work with artistic devices, in order to atract and hold the attention of readers:

"O Senhor M. C. poderá objetar-me que a sua obra não é de literatura; mas, deixando essa alegação que só pode ter base na ignorância do que seja verdadeiramente literatura - que não é o caso do autor dos Ensaios - tomo a liberdade de dizer-lhe que um escritor como ele, que muito justamente quer agir sobre o meio que o cerca, deve revestir-se de certa sedução artística, a fim de que seu livro interesse a todos. Penso que, para isso, devia escrever com seu espírito particular para o espírito geral do país, não esquecendo que esse país, para o qual escreve. é o mais bem dotado de preguiça mental que se conhece" (14).

It would seem logical that indirect representation would require more mental agility and intelligence on the part of the reader than direct representation. This is not what Lima Barreto thought, however. He considered the artist someone who does the thinking for his reader, than presents his ideas in a more perceivable or understandable form. The final understandable form Lima Barreto defines vaguely as sentimento, which can be translated roughly as either "sentiment" or "emotion":

" $E$ ' preciso que esse argumento se transforme em sentimento; e a arte, literatura salutar tem o poder de fazê-lo, de transformar a idéia, o preceito, a regra em sentimento; e mais do que isso, torná-lo assimilável à memória, de incorporá-lo ao leitor, em auxílio dos seus recursos próprios, em auxílio de sua técnica" (15)

According to this theory, it should not be obvious that the sentiments or emotions which are experienced by the readers actually belong to the author. They should either be expressed and attributed to the characters within the work or they should be aroused in the readers by the action and plot of the work.

At times Lima Barreto must have felt that the was not accomplishing, or would not accomplish his purpose. Perhaps he felt that by transforming ideas into sentiments the former were being lost. And

(14) - Lima Barreto, Impressöes de Leitura, p. 240.

(15) - lbid., pp. 61-62. 
since his opinions and their effect were more important to him, he modified his theory and introduced into his novels some direct expression. But because he felt that direct expression by itself would no longer be fiction and could not, by itself, have any repercussions in the general public, he developed a theory of mixed literary genres, in which he could alternate direct and indirect expression:

"Nós nāo temos mais tempo nem o péssimo critério de fixar rígidos generos literários, à moda dos retóricos clássicos com as produções do seu tempo e anteriores. Os generos que herdamos e que criamos estão a toda a hora a se entrelaçar, a se enxertar, para variar e atrair" (16).

From the foregoing it may be deduced that the characters and social settings which appear in Lima Barreto's novels intentionally reflect his own ideas on the individual-society relationship. Ho is not interested merely in objectively describing individuals and Brazilian society, which would be literature of customs and local color, though this, too, is a part of his creation. His own prejudices and ideas are consciously transformed and filtered through his protagonists and the social world in which they move. Since this is the case, it is logical to ask if his characters and settings can possibly reflect reality faithfully. Very rarely does an author's opinion of a social reality coincide with that reality. Lima Barreto admits in Os Bruzundangas that he purposely deforms and exaggerates social defects, in order to emphasize:

"A 'Bruzundanga' fornece matéria de sobra para livrar-nos, a nós do Brasil, de piores males, pois possui maiores e mais completos. Sua missão é, portanto, como a dos 'maiores' da Arte (de Furtar), livrarnos dos outros, naturalmente menores" (17).

One must never lose sight of the fact that Lima Barreto had a very strong prejudice against society because as a mulatto he felt he was denied social, economic, and intellectual recognition on account of his color and humble position. For everything good that happened to him, he gave credit to his individual value and effort; for everything bad that happened to him, he blamed society. Wilson Martins justly criticized his biographer, Francisco de Assis Barbosa, for believing too synpathetically in Lima Barreto's accusations against society:

"O Sr. Francisco de Assis Barbosa, como todos os que amam, caiu redondamente nessa espécie de cilada psicológica armada por Lima Bar-

(16) - Iiid., p. 116. p. 27

(17) - Afonso H. Lima Barreto, Os Bruzundangas (São Paulo, 1956), 
reto. Se jamais chega a dizer expressamente que as notas baixas tiradas pelo aluno da Escola Politécnica eram consequiência de sua cor e de sua modesta condição social; se não afirma que os seus romances são obras de arte, se não inferiores, pelo menos imperfeitas, por causa do preconceito racial vigorante contra o escritor, é evidente que não anda longe de responsabilizar a sociedade, pelo menos em parte, pelo meio sucesso do seu ídolo" (18).

The real problem with Lima Barreto, according to Martins, are his individual defects which he tried to forget, especially a lack of will power:

\footnotetext{
"Nada... teria impedido Lima Barreto de fazer o seu caminho, . se essas condições desfavoráveis não tivessem sido aceitas, como efetivamente foram, com demasiada resignação, com uma espécie de satisfação íntima, por lhe pouparem os duros esforços da luta e da conquista. Ele não era, na sociedade brasileira, o primeiro mestiço de humilde condição a tentar uma carreira intelectual: antes dele, e ao seu lado, já os Luís Gama, os Rebouças, os Patrocínio, os Cruz e Sousa, os Gonçalves Dias, tinham demonstrado que não há obstáculos intransponíveis para o verdadeiro talento, para a verdadeira vontade" (19)
}

Though Lima Barreto thought that the real-life conditions existing in the relations between the individual and his social environment, to the detriment of the individual, should be condemned, he had an entirely different attitude toward the the natural world. Just like the characters and society, nature should be explained, but instead of being condemned it should be included and treated with loving care. His attitude may be inferred from what he says about Gastão Cruls. It is noticed here that he is careful not to censure Cruls as a writer for not loving nature, but it is obvious that he would like the stories better if they did show such a love:

"Nota-se nele que o autor ama muito a vida da roça, não ama a natureza. Não há nele um toque distinto que denuncie esse amor Não é só à paisagem, mas mesmo aos bichos, aos bois, aos carneiros; o que ele ama, por assim dizer, é a vida social da roça" (20).

Lima Barreto believed that contemplation and communion with nature often gives a man relief from the problems which beset him in everyday life. He also felt that the nature of the western hemisphere (specifically of Rio de Janeiro) must be observed and dealt with li-

(18) - Wilson Martins, "Lima Barreto ou o falso boêmio", Província de São Pedro, n.o 20 (1965), p. 118.

(19) - Ibid.

(20) - Lima Barreto, Impressões de Leitura, p. 87 
terarily on the basis of personal experience rather than bookishly, from literary tradition. Though he was not a man of letters, Dom Jo5o VI provides Lima Barreto with an example of one of the first men who truly appreciated and understood Brazilian nature. The implication is that an author must treat Brazilian nature in a simple manner, seeking its essence, but only in a way that reveals his own personal feelings and comprehension:

Mesmo os nossos poetas mais velhos nunca entenderam a nossa vegetação, os nossos mares, os nossos rios; não compreendiam as nossas coisas naturais e nunca lhes pegaram a alma, o substractum ( $\mathrm{sic}$ ); e se queriam dizer alguma coisa sobre ela caíam no lugar-comum amplificado e no encadeamento de adjetivos grandiloqüentes, quando não voltavam para a sua arcadiana e livresca floresta de álamos, plátanos, mirtos, com vagabundíssimas ninfas e faunos idiotas, segundo a retórica e a poética didáticas das suas cerebrinas escolas, cheias de pomposos tropos, de rapé, de latim, e regras de catecismo literário.

Se, nos poetas, o sentimento da natureza era esse de paisagens de poetas latinos, numa diluição já tão exasustiva que fazia que os autores do decalque se parecessem todos uns com os outros, como se poderia exigir de funcionários, fidalgos limitados na sua própria prosápia, uma maior força original de sentimento diante dos novos quadros naturais que a luminosa Guanabara lhes dava, cercando as águas de mercúrio de suas harmoniosas enseadas?

Dom João VI, porém, nobre de alta linhagem e princípe do século de Rousseau, mal enfronhado na literatura palerma dos árcades, dos desembargadores e repentistas, estava mais apto para senti-los de primeira mão, diretamente. Podia ele, perfeitamentc, amar o passaredo alegre na plumagem e triste no canto, a gravidade alpestre de cenários severos, os morros cobertos de árvores de insondável verde-escuro, que descem pelas encostas amarradas umas às outras, pelos cipós e trepadeiras, até - mar fosco que muge ao sopé deles

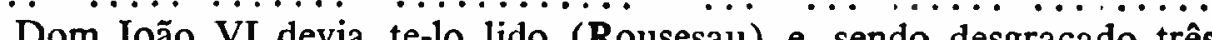
vezes, como filho, como marido e como rei, havia de encontrar a sua alma bem aberta para lhe receber as liçōes e compreender de modo mais amplo a natureza, de modo a ser solicitado para um convívio mais íntimo com as árvores, com os regatos, com as cascatas, fossem elas civilizadas, bárbaras ou selvagens (21).

For Lima Barreto, nature also is symbolical in that it contains, when explained by art, a moral lesson for man: its harmony It also provides a greater comprehension of the universe and thus at least a partial penetration into the mysteries that surround us:

"...ela (a Arte), não cansada de ligar as nossas almas, umas às outras, ainda nos liga à árvore, à flor, ao cão, ao rio, ao mar e à es-

(21) - Afonso H. Lima Barreto, Histórias e Sonhos (São Paulo, 1956), pp. $157-158$. 
trela inaccessível; ela nos faz compreender o Universo, a Terra, Deus e o Mistério que nos cerca, para o qual abre perspectivas infinitas de sonhos e de altos desejos" (22).

Whereas the individual assumes an important role in Lima Barreto's discussions of the origin of a work of art and of the work itself, in his view of the individual and society of his reading public, Lima Barreto was definitely more interested in society as a whole than in isolated individuals. He did not direct himself to an intelecctual élite but rather to the greater reading public, which would include just about anyone who could read. It was for this reason that he insisted upon simplification at every turn in his art. What he was attempting to do was to enlighten the average man in such a way as to bring about an eventual transformation of society to a better mode of existence. He wanted to communicate certain abstract truths about society and human beings in a perceivable form. It was his hope that the realization of these truths would sooner or later provoke action and ultimately lead to an improvement in social relations and interaction. To find them in abstract form, Lima Barreto turned to religion and philosophy:

"Ela (a Arte) sempre fez baixar as altas regiōes das abstraçōes da Filosofia e das inaccessiveis revelaçōes da Fé, para torná-las sensíveis a todos, as verdades que interessavam, e interessam à perfeição da nossa sociedade" (23).

The "abstract" truths turn out to be very simple moral tenets derived from the Bible, such as "Love thy neighbor. " and "Do unto others as you would have them do unto you" He believed in calling attention to common, simple, ordinary truths generally accepted by everyone but almost always ignored in real life:

"Algumas vezes é proveitoso que o nosso exame e as nossas faculdades pensantes se dirijam e repousem no evidente, no respeitado e no que está claro como água" (24).

Although he is primarily directing his preaching to the whole of society, what Lima Barreto says many times in this respect might be taken for the moral edification of individuals as well:

"No mundo, não há certezas, nem mesmo em geometria; e, se alguma há, é aquela que está nos evangelhos: amai-vos uns aos outros" (25)

(22) - Lima Barreto, Impressões de Leitura, p. 67.

(23) - Ibid.

(24) - Ibid., p. 79.

(25) - Lima Barreto, Histórias e Sonhos, p. 35. 
Lima Barreto's criticism of society is based much of the time on moral grounds, since what he saw around him was lack of understanding, if not hatred, between social classes, individuals, and nations. Undoubtedly his personal moral sensitivity was made much more acute because of the color of his skin and of his own position on society. It was probably aggravated also by the historical events of the period in which he was writing: directly preceding and during World War I. Finally, he was influenced also by an economic phenomenon: the advent of capitalism in Brazil. He thought the mad rush toward materialism and desire to acquire as such money as possible was immoral:

"A crença no todo poderio do dinheiro que entre nós, se apossou, primeiramente de São Paulo, o que foi notado por Alberto Torres, não sei em que lugar, vai avassalando todo o Brasil, matando as nossas boas qualidades de desprendimento, de doçura e generosidade, de modéstia nos gostos e nos prazeres, emprestando-nos, em troca, uma dureza com os humildes, com os inferiores, com os desgraçados, com tolas e infundadas superstições de raça, de classe, etc., nesta época de grandes e justas reivindicações, ameaça-nos de morte, ou senão, de grandes lutas sangrentas" (26).

Lima Barreto's determination to act as moral judge of society is explained in part by his belief that the church of his day, whose business was supposed to be morality was not performing its function in that sense. Ho states that the church is an accomplice in the general corruption of all of society and implies that he, as a responsible writer and in the tradition of the French philosophers of the eighteenth century, must take over the duties of the priest:

Se não estou totalmente esquecido, é tratando de Barère, num dos seus Ensaios, que Macaulay diz que os filósofos franceses do século XVIII estavam com os Evangelhos, enquanto a Igreja se havia separado deles completamente. Agora mesmo, com esse explodir ruidoso das reivindicações das classes oprimidas, aqui e ali, na América e na Europa, podemos repetir o asserto do grande escritor inglês.

Sem se poder negar à Igreja, na sua existência quase duas vezes milenar, ter presidido, favorecido e patrocinado muita reforma útil e favorável à fraternidade entre os homens, desde a Renascença para cá, porém, ela se mostra completamente impotente para continuar a fazei tal coisa.

A política da Igreja tem consistido nesses últimos tempos, em sustentar a classe poderosa no momento, com unhas e dentes, desculpar os seus erros e crimes, para poder viver; e quando ela, a classe poderosa, é derrubada e abatida, aliar-se à vitoriosa que the sucede (27).

\footnotetext{
(26) - Lima Barreto, Bagatelas, p. 191.

(27) - Ibid., p. 238.
} 
Another explanation accounting for Lima Barreto's moralistic attitude toward society was the influence he suffered from the positivistic philosophy of Auguste Comte, which had its principal disciple in Brazil in Teixeira Mendes. Though Lima Barreto made fun of its external rites and its temple of worship of humanity, he accepted many of its basic tenets, such as the necessity of a moral transformation before a social reorganization for the better could take place. The latter would be carried out with the help of science. Lima Barreto also was influenced by, even though he did not accept completely, Comte's ideas of the development and hierarchy of sciences. According to this theory, the science of sociology is the ultimate result of the evolution of all other sciences and will be the means of organizing society in a better way, perhaps after the moral transformation has already occurred (28).

According to Lima Barreto, the science of sociology in his epoch had not yet had time to gather enough material to arrive at any decisive conclusions, but he thought that it eventually would. The duty of literature and all writers in general was to contribute to this young science by helping to explain the mysteries of social life:

O dever, portanto, de todos nós é colaborar, na medida das nossas forças, para que fiquem explicados $D$ mais claramente possível os mistérios da nossa vida social, a fim de tirar das mãos de feiticeiros e charlatães e do seu séquito de piratas especuladores de toda a sorte, a direção das nossas sociedades, para entregá-la aos que estudaram e meditaram sobre aquilo que, de positivo e verificado, os sábios desvendaram relativamente à sua existência e ao seu progresso, aconselhando tais e quais medidas práticas, destinadas a organizá-la da forma mais perfeita possível com a qual se obtenha a mais completa felicidade para as suas partes (29).

As is seen from the above quotation, Lima Barreto places literature at the service of sociology. This would help bring about the eventual change in society that he longed for so much. In reference to the moral reformation that must precede any social upheaval, however, Lima Barreto seems to have faith in literature apart from sociology as a self-sufficient force. For him the mission of literature was to break down the barriers of incomprehension between men of different races, epochs, beliefs, social classes (perhaps the first step in a pacific revolution) by explaining one to the other and showing them the bond

(28) - Positivism in Brazil and its possible influence on Lima Barreto is treated by Francisco de Assis Barbosa in his biography A Vida de Lima Barreto (Rio de Janeiro, 1959), pp. 59-72.

(29) - Lima Barreto, Impressões de Leitura, pp. 239-240. 
they all have in common: sorrow and suffering. The basic sentiment Lima Barreto hoped to arouse in his reading audience was one of compassion:

“... ela (a Arte) explicou e explica a dor dos humildes aos poderosos e as anyustiosas dúvidas destes, àquêles; ela faz compreender, uns aos outros, as almas dos homens dos mais desencontrados nascimentos, das mais dispersas épocas, das mais divergentes raças; ela se apieda tanto do criminoso, do vagabundo quanto de Napoleão prisioneiro ou de Maria Antonieta subindo à guilhotina..." (30).

The combination in Lima Barreto of what are basically religious sentiments and a fascination for science and the scientific method in order to bring about social change is an unusual, perhaps contradictory one. He admitted that his own knowledge of sociology was weak:

" $E$ ' verdade que ... ainda mais por sentir um alto destino nas letras, sou levado a pensar mais além do que fazem os simples literatos elegantes, limpinhos e bonitotes sobre os problemas que a sociedad: põe; mas isto não quer dizer que me discipline nesse estudo e tenha nele qualquer orientação' '(31).

He also viewed so-called scientific truths with doubt and took refuge in the Scriptures as the basis for his own thought and action; however, he felt that science was useful if one did not expect from it ab olute perfection and absolute truth on the practical level of everyday life. From a reviw he wrote of a book Knowing and Life by Mrs. Joachin Macran and W. Smith Bradley, he seems to agree with the authors when they affirm that individual lives, and therefore society, cannot be ruled by the strict logic of science alone but must 'be guided in part by morality and religious indoctrination:

"Os Senhores Macran e Bradley notam muito bem que, em tese, o método que nesse longo trato de vida o romancista seguiu foi o dedutivo; mas, na verdade, em vários episódios durante ele, obedeceu \& outros métodos, às vezes confundindo-os e embrulhando-os, empregando até processos que escapam à lógica e só interessam à Moral prática e à doutrinação religiosa, que, talvez, sejam uma e a mesma coisa, no fim de contas" (32).

Lima Barreto a'so felt that art and lìerature were a kind of science in their processes:

(30) - Ibid., p. 67

(31) - Ibid., p. 238.

(32) - Ibid., p. 210. 
"Eu não acredito absolutamente na eficácia da ciênci: para fazer poetas e literatos; às vezes mesmo a julgo nociva; mas te $\eta^{2}$ o para mim que o processo é o mesmo na arte e na ciência: um acordo entre o oculto e o visível, uma relação entre fatos que, só com os instrumentos do pensamento, ganham uma explicação" (33).

Accordingly, the author must follow a kind of mathematical formula to realize his social purpose: he transforms ideas into sentiments and these sentiments will cause the individual reader to perform the reverse process; that is, to proceed from the particular sentiment to the general idea:

"A arte, incluindo nela a literatura, continua Guyau, é a expressão da vida refletida e consciente, e evoca em nós, ao mesmo tempo, a consciência mais profunda da existência, os sentimentos mais elevados, os pensamentos mais sublimes. Ela ergue o homem de sua vida pessoal a vida universal, não só pela sua participação nas idéias e crenças gerais, mas também ainda pelos sentimentos profundamente humanos que exprime' '(34).

The difference between mathematics and art, however, is that mathematics is purely abstract; art deals with particular, human, and very slippery quantities: sentiments and emotions.

Lima Barreto anticipates the movement in world literature called literatura comprometida which Guillermo de Torre (35) states began shortly after World War I. He believed that every writer should be committed to resolving the outstanding social problems of his time. He sharply criticized writers like Coelho Neto who failed to do so:

O Senhor Coelho Neto, que surgiu para as letras nas últimas décadas do século XIX, não se impressionou com as mais absorventes preocupações contemporâneas que lhe estavam tão próximas.

As cogitações políticas, religiosas, sociais, morais, do seu século, ficaram-lhe inteiramente estranhas. Em tais anos, cujo máximo problema moral, problema que interessava todas as inteligências de quaisquer naturezas que fossem, era uma reforma social e moral, o senhor Neto não se deteve jamais em examinar esta trágica angústia do seu tempo, não deu para o estudo das soluções apresentadas um pouco do seu grande talento, nem mesmo tratou de conhecer o positivismo que lhe podia abrir grandes horizontes (36).

(33) - Lima Barreto, Diário Intimo, p. 133.

(34) - Lima Barreto, Impressões de Leitura, p. 66.

(35) - Guillermo de Torre, Problemática de la literatura (Buenos Aires, 1951), p. 18 .

(36) - Lima Barreto, Impressões de Leitura, p. 76. 
From the above citation it is clear that Lima Barreto certainly did not believe in "art for art's sake" Much more important to him than art, merely a means, was the idea behind the work, the message to be communicated, the social transformation to be realized. Ho was more interested in the result of the work than the work itself. Georgi Plekhanov has stated that artists who believe in "art for art's sake" necessarily feel a "hopeless contradiction between their aims and the aims of the society to which they belong. Artists must be very hostile to their society and they must see no hope of changing it" (37). All of the preceding quotation except the last part applies to Lima Barreto. He was certainly hostile to society but he did see hope of changing it. He thought he had no chance of seeing the reform he wanted to help bring about in his life time, but projected himself into the future with hope. Jean-Marie Guyau was his guide in this prophetic attitude:

"Que me importa o presente! No futuro é que está a existência dos verdadeiros homens. Guyau a quem eu não me canso de citar, disse em uma de suas obras, estas palavras que ouso fazê-las minhas:

"Porventura sei eu se viverei amanhã, se viverei mais uma hora, se a minha mão poderá terminar esta linha que começo? A vida está, por todos os lados, cercada pelo Desconhecido. Todavia executo, trabalho, empreendo; e em todos os meus atos, em todos os meus pensamentos, eu pressuponho este futuro com o qual nada me autoriza a contar. A minha atividade excede em cada minuto $o$ instante presente, estende-se ao futuro. Eu consumo a minha energia sem recear que este consumo seja uma perda estéril, imponho-me privações, contando que o futuro as resgatará e sigo o meu caminho. "(38).

Much of what Lima Barreto says with regard to the moral purpose of literature, the concern of literature for contemporary problems, and the transformation of society had been said more than thirty-five years earlier by Eça de Queiroz who in turn took most of his ideas from Proudhon (39). Literature which acts in this way Lima Barreto calls "literatura militante", a term which he also borrowed from Eça (40). The choice of terminology was an unfortunate one since standing alone without explanation it has a purely destructive and

(37) - Quoted by René Wellek and Austin Warren, op. cit., p. 101.

(38) - Lima Barreto, Impressões de Leitura, pp. 68-69.

(39) - Viana Moog, Eça de Queiroz e o século XIX (Porto Alegre, 1938), pp. 156-159. Antero de Quental was angered that Eça should dare to talk about the paintings of Courbet, using the language of Proudhon, without aver having seen the paintings himself.

(40) - Lima Barreto says it is used in Prosas Bárbaras; I did not find " there but it is used in $A$ Ilustre Casa de Ramires in a slightly different sense Joaquim M. Eça de Queiroz, A Ilustre Casa de Ramires [Porto, s. d.], p. 19). 
violent connotation. In reality, Lima Barreto's purpose, going beneath external appearances, was a constructive and noble one, as he himself explains:

Isto em geral dentro daquele preceito de Guyau que achava na obra de arte o destino de revelar umas almas às outras, de restabelecer entre elas uma ligação necessária ao mútuo entendimento dos homens.

Eu chamo e tenho chamado de militantes, às obras que têm seme-

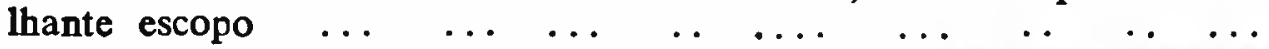

Hoje, quando as religiōes estão mortas ou por morrer, o estímulo para elas é a arte. Sendo assim, quem, como eu literato aprendiz que sou, cheio dessa concepção, venho para as letras disposto a reforçar esse sentimento com as minhas pobres e modestas obras (41).

\section{Conclusions and Resumé}

The relation between the individual and society in the literary theory of Lima Barreto takes three principal forms. The first is the relation between the individual author (himself) and society to the extent to which the relation determined his purpose in writing, the elements which would appear in his literary work, and the amount of freedom has was allowed or felt he could exercise in expressing his ideas. The second is the relation between the individual characters and the society of his world of fiction. The third is the relation between the individual author (himself) and society in the way and to the extent he hoped to influence his reading audience as a result of his literary work.

In the first instance, Lima Barreto believed that an author must not allow the opinions and pressure of certain classes and professional groups (especially the upper ranks of newspapers and publishing houses or their controlling interest) to determine his own opinion. He must constantly struggle against those suppressive elements in his environment, in order to be outspoken, individualistic, and personal in what he writes. Though the society which surrounds him will necessarily be reflected in his works, his attitude towards that society will be original, a result of his own experiences and independent meditation. Since from his personal experiences and intellectual reflection Lima Barreto had arrived at the conclusion that society is harmful to the individual in the influences it exerts upon him, he resolved that his literature should have as a purpose an exposé of that situation and that it should offer an alternative course for society

(41) - Lima Barreto, Impressões de Leitura, p. 72. 
In the second instance, Lima Barreto felt that the external world of society must be described and explained in great detail in a work of fiction since the most important element in literary art, the characters, cannot be understood without it. Characters cannot move in a vacuum. Their actions and motives must be thoroughly clarified by showing how the social world acts on them. The individual character, however, must not be shoved into the background because of excessive attention to particulars of his environment. He must occupy the foreground since he is the primary focus of the literary work. Considerable space in it must be devoted to psychological penetration of the individual character and the explanation of his psychological motivation. Fiction deals with a particular individual character in a particular social environment. In Lima Barreto's fiction they exemplify his general, abstract ideas about the individual's relationship to society and what is wrong with it. The creation of fiction for him is then a process from the general to the particular. The process of the reader is the opposite: from the particular to the general idea. In this way, according to $\mathrm{Li}$ ma Barreto, the reader should arrive indirectly and perhaps subconsciously, to the same conclusions at which he arrived and were the basis of his work of art.

In the third instance, Lima Barreto hoped to reform society in a moral sense. He wanted all classes of society, all races, all nationalities to understand and love one another in the Biblical and humanitarian sense. He desired to bring this about by showing them the one link they all had in common: suffering and sorrow $\mathrm{He}$ wished also to reveal the evils of society by making his reading public aware that they existed. He believed that the way to create this awareness was an alternation of indirect artistic means (satire and irony) and direct denunciation. Lima Barreto thought that all individual readers, having become aware of the bad things in society and in themselves and of the things they had in common with all human beings, would perhaps eventually act to improve society.

The relation between the individual and nature in Lima Barreto's theory of literature is important in several ways. First, he loved nature and thought that this love should be shown in his literature. This positive aspect forms a sharp contrast, artistically, with his distrust and sharp criticism of society. Second, he felt that nature description in literature was not justified unless based upon personal experience of the author. Nature which is invented merely to fill in the background of a novel is false and unjustifiable. Nature should be expressed in simple terms which attempt to arrive at its essence, not in empty rhetorical language. Third, in relation to the individual characters of 
his literature Lima Barreto considered the external world of nature an essential element, along with society, in explaining a character. He felt also that it offered consolation and pleasure to man in the midst of suffering and that it contained a profound moral example or lesson within itself for all of humanity: harmony. 